\title{
$\boldsymbol{\nabla}$ Artikkeli
}

\section{Juhannustanssien nopea roihu ja Facebook-keskustelun tunneintensiteetit}

Juhannuksena 2012 We Love Helsinki -kollektiivin avoimella Facebooktapahtumasivulla käytiin kiivasta keskustelua heteronormatiivisuudesta, syrjinnästä, klubikulttuureista, suvaitsevaisuudesta ja suvaitsemattomuudesta. Viisi päivää kestänyttä debattia kommentoitiin laajalti sosiaalisessa mediassa ja se nousi jopa pienimuotoiseksi kansalliseksi uutiseksi. Artikkeli esittelee debatin keskeisiä teemoja painottuen verkkokeskustelujen tunnedynamiikan käsitteellistämiseen. Aineistona on arkistoitu, 728 kommentin mittainen juhannustanssi-keskusteluketju sekä sitä koskevat uutis- ja blogitekstit. Verkkokeskustelujen intensiteetti kasvaa nopeasti kommenttien kärjistyessä ja tunneilmaisujen roihahdellessa. Artikkeli esittää, että tällainen affektiivinen tahmeus saa kävijät viipymään keskustelun parissa ja osallistumaan siihen: niinpä myös toisten käyttäjien tietoinen provosointi eli trollaus kasvattaa keskustelun tahmeutta. Samalla nettikeskustelun tunnedynamiikat liittyvät myös nettialustojen - tässä tapauksessa Facebookin - rajoituksiin, mahdollisuuksiin ja erityispiirteisiin. Artikkeli erittelee juhannuskeskustelun dynamiikan erityispiirteitä väittäen tunneintensiteettien sekä ajavan verkkokeskusteluja, fragmentoivan niitä että kiinnittävän käyttäjiä tiettyihin alustoihin, ketjuihin ja ryhmiin. Netin käyttäjälojaalisuuteen ja huomiotalouteen yhdistetty termi "tahmea sisältö" onkin hedelmällisesti yhdistettävissä affektiivisen tahmeuden käsitteeseen nettisisältöjen koukuttavien - niin viihdyttävien kuin häiritsevienkin - piirteiden analyysissä.

AVAINSANAT: Nettikeskustelu, affekti, Facebook, tunneintensiteetti, trollaus, meemit

K esäkuussa 2012 Ylen verkkouutiset ja Iltalehti julkaisivat uutisjutut otsikoilla "Juhannustansseista kiihkeä homokeskustelu netissä" (Yle 26.6.2012) ja "Toimitusjohtaja vastaa: Nuorten juhannustansseissa ei syrjitty homoja!" (IL 27.6.2012). Perinteisin journalistisin kriteerein arvioituna juttujen uutisarvo oli matala. Niiden mukaan kollektiivi We Love Helsingin (WLH) järjestämään Juhannustanssit klubi-iltaan' osallistunut nainen oli närkästynyt kahden DJ:n välispiikeistä ja kirjoittanut niiden heteronormatiivisuutta kritisoivan kommentin tapahtuman avoimelle Facebook-tapahtumasivulle. Viesti oli sittemmin herättänyt sosiaalisessa mediassa vilkasta 
keskustelua seksuaalivähemmistöistä, tasa-arvosta ja esitetyn kritiikin oikeutuksesta. Uutisjuttujen pääasiallinen sisältö oli, että tällaista keskustelua käydään. Debatin aloittanut viesti oli seuraavanlainen:

Hei! Olisin kaivannut etukäteen tietoa siitä, että kyseessä oli eksklusiivisesti heteroseksuaaleille suunnatut tanssit, jotta olisin osannut jättää tulematta. Olen pitänyt tätä We Love Helsinkiä -konseptia raikkaana, enkä siksi osannut odottaa hetero-eksklusiivisuutta. Tämä tuli esille siinä, kun dj kuulutti perinteisen iskelmän puolella "Lavalla tanssi kolme naisparia, skarpatkaaa vähän miehet, ja hakekaa!". Ikään kuin naiset eivät voisi ensisijaisesti haluta tanssia nimenomaan naisten kanssa, ja ikään kuin naisten keskenään tanssiminen olisi vain "hupitanssia". Factoryn puolella taas kuulutettiin, että "Naiset ovat erityisen kauniita, koska ovat laittautuneet - he ovat laittautuneet teitä varten, pojat". Luulin, että juhannustanssiperinnettä olisi enemmän uudistettu tässä tapahtumassa, mutta taitaa vielä olla vähän liian aikaista sellaiselle :) (1/1: postitettu 23.6.2012, 209 tykkäystä)

Viestin lähettäjä, jonka olen anonymisoinut yleisimpien kotimaisten etu- ja sukunimien mukaan "Maria Korhoseksi", poisti keskusteluketjun viisi päivää myöhemmin. Siihen menneessä ketjuun oli tullut yli 700 kommenttia. Toisin sanoen nettikeskustelusta muodostui nopeasti kiihtyvä väittely, johon yhä uudet keskustelijat osallistuivat. Debatti myös laajeni tapahtumasivulta muihin Facebook-keskusteluihin, blogeihin ja verkkouutisiin: feministisen Tulva-lehti analysoi debattia blogissaan (25.6.2012), mediaopiskelijoiden Lehtilehti laati parodiajutun otsikolla "Kansa raivostui mielensäpahoittajien kohukesäjuhlilla" (26.6.2012), Kansan Uutisten Kaasuputki-blogi nimesi debatin kaikkien aikojen järjettömimmäksi keskusteluksi (26.6.2012) ja Helsingin Sanomien Nyt-liite julkaisi verkkosivuillaan "We Love Helsinki Gaten", jossa se kehotti lukijoita äänestämään, "kenen joukoissa seisot!" (26.6.2012). Tämä keskikesän virtuaalikokko vaikutti kaiken kaikkiaan suhteettomalta. Kuinka yksi Facebook-seinäviesti onnistui herättämään moiset liekit?

Vastaan seuraavassa tähän kysymykseen analysoimalla juhannustanssikeskustelua tunneintensiteetin ja tahmeuden käsitteiden varassa. Erittelen WLH-keskustelun keskeisiä teemoja ja vaiheita ja väitän, että vaikka keskusteluketju oli tapauksena erityinen, se oli samalla myös dynamiikaltaan yleisemmin tunnistettava. Väitän myös, että tämän vuoksi tapauksen erittely voi auttaa hahmottamaan hyvinkin erilaisille tekstipohjaisille nettikeskusteluille ominaista näkökantojen kärjistymistä ja fragmentoitumista. Tämä kärjistyminen on erityisen selvää yhteiskunnallisiin kysymyksiin keskittyvissä nettidebateissa (vrt. Robinson 2005), mutta sitä ilmenee yhtälailla myös verkkolehtien kolumneja koskevissa kommenttiketjuissa tai Suomi 24:n tai Vauva-lehden keskustelufoorumien arkisiin teemoihin keskittyvissä mielipiteenvaihdoissa, joihin osallistuu ja joita seuraa laajahko, näkemyksiltään kirjava ihmisjoukko. Nettikeskustelun ja -debatin välisiä eroja voi yhtäältä hahmottaa terävyyden, vastakkainasettelun ja intensiteetin asteina. Toisaalta kyse on keskustelun saamasta huomiosta sekä kyseisellä keskustelukanavalla että sen ulkopuolella - eli debattiin kohdistuvan laajemman huomion ja julkisuuden asteesta. Kaikki keskustelut eivät kiihdy kiistaksi, eikä kaikista 
kiistoista muodostu debatteja. Keskustelutyylit ja -taktiikat saattavat kuitenkin olla hyvin samanlaisia.

Vaikka käsittelenkin juhannustanssikeskustelun erityisiä teemoja, äänenpainoja ja käänteitä, artikkelini fokus on nettikeskustelujen ja trollauksen - eli toisten käyttäjien tietoisen provosoinnin - tunnedynamiikan käsitteellistämisessä kulttuurisen mediatutkimuksen ja affektitutkimuksen viitekehyksessä. Systemaattisen sisällön-, keskustelun- tai diskurssianalyysin asemesta erittelen, mihin kommentteihin keskustelijat juhannustanssiketjussa erityisesti tarttuivat, kuinka keskustelua koetettiin kiihdyttää ja sysätä uusiin suuntiin, miten muita keskustelijoita nimettiin ja luokiteltiin ja kuinka keskusteluketjun intensiteetti muuttui ja eli. Keskityn tässä viestiketjun tykkäyksiin, nimittelytapoihin, hymiöiden käyttöön, provosointi- ja trollausyrityksiin sekä sen meemejä koskeviin kommentteihin. Kielellisten käytäntöjen erittelyn rinnalla pohdin, miten Facebookin informaatioarkkitehtuuri - tavat, joilla muiden tuottama ja kierrättämä aineisto saatetaan käyttäjän näkyville, tämän kommentoitavaksi, jaettavaksi ja tykättäväksi - vaikutti debatin dynamiikkaan. Viestintäalustoina Facebookin tapaiset sosiaalisen median palvelut ohjailevat hyvinkin konkreettisin tavoin käyttäjiensä huomion kiinnittymistä ja vuorovaikutusmahdollisuuksia (vrt. Karppi 2014). Onkin olennaista kysyä, kuinka tämä tapahtuu ja vaikuttaa viestinnän saamiin muotoihin.

Artikkelini premissinä on, että tunneintensiteetti on ollut kaikenlaisten nettikulttuurien olennainen elementti verkkofoorumien vihapuheesta sähköpostilistojen sinnikkääseen trollaukseen ja kiihkeistä, nopeasti syttyvistä ja sammuvista nettiromansseista viraalivideoiden laajamittaiseen kierrätykseen. Tunneintensiteetti on kuitenkin ollut viimeisen kahden vuosikymmenen ajan nettitutkimuksessa hyvinkin alitutkittu ja -teoretisoitu teema. Artikkelissani laajennan osaltani nettitutkimuksen analyyttistä fokusta väittäen, että tunneintensiteetti sekä ajaa verkkokeskusteluja että kiinnittää käyttäjiä tiettyihin alustoihin, keskusteluketjuihin ja ryhmiin. Analysoin Facebookin erityisyyttä nettikeskustelun alustana ja juhannustanssiketjun yhteyksiä aiemmin tutkimuksen kohteena olleeseen "fleimaukseen" (provosoivaan riitelyyn), trollaukseen, hymiöiden käyttöön sekä nettisisällön leviämiseen ja tahmeuteen osoittaen, miten tunneintensiteetti kasvaa, laajenee ja fragmentoituu nettialustoilla. Esitän lisäksi, että lähinnä netin käyttäjälojaalisuuteen ja huomiotalouteen yhdistetty termi "tahmea sisältö" on hedelmällisesti yhdistettävissä affektiivisen tahmeuden käsitteeseen nettisisältöjen koukuttavien - sekä viihdyttävien että häiritsevien - piirteiden analysoinnissa.

Affektiivisuudella tarkoitan kohtaamisia, joissa kehot, tekstit, kuvat ja ajatukset häiritsevät ja koskettavat toisia kehoja ja mahdollisesti asettavat ne liikkeeseen (ks. Ahmed 2004). Affekti on kehollinen intensiteetti, joka syntyy ja elää kohtaamisissa maailman kanssa ja muovaa sekä meitä että tapojamme olla yhteydessä muihin. Tunneintensiteeteistä kirjoittaessani en kuitenkaan tee ehdotonta erottelua affektin ja emootion (yksilön sisäistetty ja tulkittu tunnetila tai ympäristöä koskeva arvostelma) välille, sillä näen Sara Ahmedin (2010a, 32) tapaan affektin ja emootion liukuvan toisiinsa ja liimaantuvan yhteen arkisissa kohtaamisissa. Näin ymmärrettyinä sekä 
nopeat affektiiviset hätkähdykset että emootiot ovat saman tunnetekstuurin säikeitä, jotka sysäävät toinen toistaan liikkeeseen: affektiiviset reaktiot eivät ole kokemuksen tasolla erotettavissa muistoista, arvoista ja kokemuksista (myös Paasonen 2011, 26-27).

Vaikka juhannustanssikeskustelun kaltaiset debatit käynnistyvät ja kehittyvät nopeasti, niissä on kyse esikognitiivisen (ja esilingvistisen) aistimuksen sijaan kirjallisista käytännöistä. Onkin syytä huomioida, ettei verkkokeskustelua analysoimalla ole sinänsä mahdollista tutkia osallistujien affekteja tai emootioita, vaan ainoastaan niiden tekstuaalisia esityksiä ja julkaistujen viestien välisiä yhteyksiä. ${ }^{2}$ Viittaankin tunneintensiteetillä keskustelujen dynamiikkaan: tapaan, jolla tunteen ilmaukset kasvavat, kasaantuvat, liukuvat, kiinnittyvät joihinkin kohteisiin toisten sijaan ja samalla ajavat verkkokeskusteluja eteenpäin.

Aineistoni koostuu arkistoimistani 173 keskustelijan lähettämästä 728 kommentista, ja se kattaa osallistujien itse poistamia ja mahdollisesti aivan viimeisiä kontribuutioita lukuun ottamatta koko keskusteluketjun. Olen säilyttänyt kommenttien kieliasun lyöntivirheineen. Aineisto on anonymisoitu ja kuhunkin kommenttipuheenvuoroon viitataan kahdella numerolla: näistä ensimmäinen viittaa sen järjestykseen ketjussa ja jälkimmäinen siihen, monentena sen lähettäjä on ketjuun osallistunut. ${ }^{3}$ Viesti (1/1) viittaa järjestyksessä ensimmäiseen, Korhosen lähettämään viestiin ja (728/130) ketjun viimeiseen kommenttiin. Viimeinen uusi osallistuja liittyi mukaan kommentissa (726/173). Olen lisäksi keskustellut tapauksesta Korhosen ja WLH:n toiminnanjohtaja Timo Santalan kanssa. ${ }^{4}$

\section{Liimainen intensiteetti}

Tahmealla verkkosisällöllä tarkoitetaan videolinkkejä, kommentointimahdollisuuksia, testejä ja pelejä eli viihteellistä sisältöä, jonka avulla käyttäjiä houkutellaan pysymään kyseisellä sivustolla, palaamaan sille yhä uudelleen ja jakamaan edelleen huomionsa vanginnutta sisältöä. Tahmeus sekä motivoi netin viihteellisiä käyttöjä että toimii kilpailuvalttina netin huomiotaloudessa, jossa käyttäjien määrä kasvattaa sivuston arvoa mainospaikkana - ja Facebookin tapauksessa vaikuttaa suoraan yhtiön osakkeiden arvoon. Tahmeuden voi ymmärtää myös affektiivisena arvona, joka määrittää sitä, millaista sisältöä tai sivustoa pidetään kiinnostava, hauskana, tärkeänä tai törkeänä ja siksi huomionarvoisena (vrt. Coté \& Pybus 2007).

Marxin pääoman teoriaan viittaavalle Ahmedille $(2004,90)$ tahmeus merkitsee affektiivista arvoa. Nettiin sovellettuna tämä merkitsee sitä, että mitä enemmän objekti - kuten Facebookissa jaettu viesti, iltapäivälehden uutisjuttu tai hassu kissavideo - kiertää, sitä korkeampi affektiivinen arvo sillä on ja sitä tahmeammaksi se muodostuu. Ja tosin päin, mitä tahmeampi objekti on, eli mitä herkemmin affektit kiinnittyvät siihen, sitä enemmän se kiertää. Tahmea objekti on siis päällystetty affektiivisilla kerrostumilla - ikään kuin affektein kyllästetty. Satojen ärtyneiden ja huvittuneiden kommenttien, tuhansien tykkäysten ja laajojen lukijajoukkojen myötä juhannustans- 
sikeskustelusta tuli nopeasti tahmea. Tapausta käsittelevät blogitekstit ja uutisjutut herättivät uusien osallistujien ja lukijoiden kiinnostuksen, kommentit karttuivat ja ketjun tahmeus - ja sitä kautta sen huomioarvo - jatkoi kasvamistaan.

Facebook-keskustelujen dynamiikkaa ja yksittäisten kommenttien tahmeutta voidaan osin hahmotella niiden saamien tykkäysten kautta. Tykkäykset kertovat siitä, kuinka huomio kiinnittyy joihinkin kommentteihin ja kenties liukuu toisten yli. Käyttäjän tekemä tykkäys näkyy tämän Facebook-ystävien ticker-uutisvirrassa tehden sen näkyväksi ja kasvattaen tykätyn kommentin huomioarvoa. Korhonen oli keskusteluketjun selvästi aktiivisin osallistuja, sillä hän lähetti kaikkiaan 55 kommenttia. Näistä ensimmäinen sai 209 tykkäystä, enemmän kuin mikään muu kommentti koko ketjussa. Toiseksi tykätyin kommentti oli "Trolli-Finlandia approves this thread" (265/52). Sen lähettäjä, kirjallisuuden Finlandia-palkinnon mukaan mallinnettu Trolli-Finlandia jakaa vuosittaisen kunnianosoituksen parhaalle kotimaiselle trollille. Juhannustanssien DJ, joka oli kehottanut miehiä hakemaan naisia tanssimaan, sai kommenteilleen seuraavaksi eniten tykkäyksiä (171 ja 155). Pitkissä ja perusteellisissa kommenteissaan DJ kirjoitti klubikulttuureja ja tanssietikettiä koskevista kokemuksistaan ja tiedostaan selittääkseen välispiikkiään ja pyysi anteeksi mahdollisesti aiheuttamaansa mielipahaa (4/4, 312/4). DJ:n viestiin vastaava Korhonen korosti, ettei hän ollut loukannut tunteitaan vaan kyse on periaatteesta. Lisäksi hän kiitti DJ:tä tämän vastauksesta ja toivotti mukavaa klubi-iltaa hymiön kera (71/1).

Tämä ei kuitenkaan lopettanut ketjua, joka fragmentoitui nopeasti vastakkainasetteluiksi ja kärjistyksiksi. Pitkät ja analyyttiset kommentit, henkilökohtaiset hyökkäykset, epäuskoiset huudahdukset ja ketjua koskevat yleisluonnehdinnat seurasivat toinen toisiaan. Ennen kun debatti nousi uutisaiheeksi, se keskittyi pääasiallisesti heteronormatiivisuuteen, seksuaalisten ja etnisten vähemmistöjen kokemaan häirintään, paritanssikonventioihin, klubikulttuureihin, sosiaalisiin ja yhteiskunnallisiin valtasuhteisiin sekä Korhosen esittämän kritiikin oikeutukseen. Ketjun edetessä ja sen saaman huomion kasvaessa yhä uudet käyttäjät liittyivät mukaan ilmaisemaan yllätystä, ärtymystä ja huvittuneisuutta, lisäämään absurdeja kommentteja ja linkkejä, hyökkäämään toisia keskustelijoita vastaan ja komppaamaan näitä. Positiivisen ja negatiivisen tunteen ilmaukset kerrostuivat toistensa päälle intensiteeteiksi, jotka elivät käyttäjien huomion ja kiinnostuksen kiertäessä ja liikkuessa.

Mediatutkija Richard Grusinin $(2010,127)$ mukaan nykymediakulttuuri tähtää negatiiviselta yllätykseltä suojautumiseen, negatiivisten affektien minimointiin ja positiivisten optimointiin. Grusin havainnollistaa väitettään Facebookin tykkäysnapeilla, joiden avulla käyttäjä voi ilmaista pitävänsä viesteistä ja linkeistä, muttei ilmaista negatiivisia tuntemuksia (emt. 4). Facebookin käyttöliittymä kierrättää kannustavasti ylöspäin nostettuja peukaloita, pirteitä keltaisia hymiöitä ja vaaleanpunaisia sydämiä ja pyrkii siten kehystämään keskustelut positiivisen affektin kautta. Juhannustanssikeskustelu tekee kuitenkin selväksi, kuinka positiiviset ja negatiiviset tunneintensiteetit kasautuvat ja limittyvät toisiinsa. Kyse ei ole vain hyvien tuntemusten optimoinnista tai kielteisten poiskitkemisestä, vaan näiden välisestä jatkuvasta, dynaamisesta liikkeestä (myös Paasonen 2011, 231-240). 
Nopean tunneintensiteetin etsintä ohjaa käyttäjien liikkeitä hedän selatessaan sivustoja, tiedostoja ja keskusteluketjuja: Facebookiin ja Twitteriin palataan useita kertoja päivässä ja ällistyttäviä kuvia lupaavia uutislinkkejä klikataan toivoen, että jokin niistä koskettaa. Uteliaisuus, kiinnostus, huvittuneisuus, häpeä, ilo, kiintymys ja ärtymys sekä riitelevät keskenään että nivoutuvat yhteen. Sosiaalisesta mediasta kirjoittava Jodi Dean (2010, 95-96) kuvailee, kuinka affektiivisuus karttuu "viestinnässä sen itsensä tähden, kommentoinnin, muistiinpanojen ja linkkien lisäämisen loputtomassa kehämäisessä liikkeessä, uusien ystävien ja seuraajien tuomisessa, moninaisten viestintäalustojen ja laitteiden kerrostuneisuudessa ja vuorovaikutuksessa". Mutta jos mikään ei vangitse tahmeudellaan huomiota, ei se myöskään kiinnosta, vaan tylsistyttää.

\section{Kuumia tunteita}

1990-luvulla tutkijat ja toimittajat pohtivat verkkoviestinnän aggressiivista ja provosoivaa erityislaatua Usenetin uutisryhmissä, sähköpostilistoilla, IRCissä ja sähköisillä ilmoitustauluilla (eli "purkeissa"): miksi ihmiset pyrkivät tietoisesti ärsyttämään toisiaan ja miksi mitä moninaisemmat, näennäisen asialliset keskustelut karkaavat pikavauhtia sanasodiksi? Verkkoviestinnän psykologiaa pohtinut Katharine Wallace (1999) yhdisti aggressiivisuuden nimettömyyteen ja heikkoon sosiaalisuuteen. Olettaessaan, ettei heitä voida tunnistaa, käyttäjät tempautuvat ilkeilemään estottomammin kuin kasvokkaisviestinnässä (myös Herring ym. 2002). Nimettömyyden illuusio siis lietsoo aggressiivisuutta, eivätkä käyttäjät oivalla, että jäljitettävyys on sisäänrakennettu heidän käyttämiinsä sovelluksiin (esimeriksi IP-osoitteiden ja evästeiden muodossa). Mediatutkija Mark Dery $(1994,1)$ kirjoitti runollisesti, kuinka "sähköisen viestinnän aavemainen luonne - lihaksi tullut sana, päätelaitteen ruudulla leijuviksi sanoiksi uudelleeninkarnoitunut lähettäjä - kiihdyttää vihamielisyyksien kärjistymistä kun tunteet leimahtavat; ruumiittomat, joskus salanimiset kisaajat tuntevat voivansa heitellä loukkauksia ilman rangaistusta (tai ainakin ilman ruumiillisen haitan pelkoa)". Dery totesi edelleen, että hymiöiden käytöstä huolimatta väärinymmärryksiä versova verkkokeskustelu saattaa olla affekteiltaan latteaa (Emt., 2-3).

Hymiöitä käytetään välittämään tunnetta, jota ilmaistaisiin muutoin äänensävyn, puheen intensiteetin, rytmin, painotusten ja voimakkuuden sekä kasvonilmeiden ja eleiden avulla (Walther \& D’Addario 2001). Hymiön käyttöä ehdotettiin tiettävästi ensi kertaa 1970-luvun lopulla hillitsemään tietojenkäsittelytieteen ammattilaisten nopeasti kuumenneita ja riitaisia sähköpostikeskusteluja: kenties ennalta arvattavasti ehdotus herätti aggressiivista pilkkaa ja johti kärkeviin verbaalisiin hyökkäyksiin ehdotuksen tekijää vastaan (Hafner \& Lyon 1996, 217-218). Sittemmin asemansa vakiinnuttaneiden hymiöiden avulla pyritään varmistamaan, että tarkoitettu nokkeluus, hauskuus, sarkasmi tai ironia tulee varmasti huomatuksi ja ymmärretyksi. Hymiöitä viljeltiin juhannustanssikeskustelussa aina Korhosen ensimmäisestä viestistä lähtien. Hänen hymiönsä tulkittiin kuitenkin ambivalenteiksi, jopa vihamielisiksi: 
Maria antoi kyllä täysin asiaankuuluvaa palautetta, mutta tapa oli täysin väärä. Jo pelkästään se, että se oli julkistettiin fabossa (vaikka yleistä tietoisuutta ja kaikkien mielipiteitä kunnioitankin) on naurettavaa ja huomionhakuista. Sanavalinnat taas olivat tahallisen provosoivia ja sarkastisia sekä välillä suorastaan vittuilua. En voi uskoa että niillä olisi mitenkään ainakaan edistetty asiaa. ... En toivoisi että kukaan näkisi tätä asiaa naurettavana, mutta Marian oma pikkuvittuilu on saanut sen aikaan. Se, että heittää parit hymiöt kommenttejen perään ei todellakaan auta asiaa vaan provosoi ihmisiä vain lisää. :):) (165/32, 29 tykkäystä)

Hymiöiden välittämän ystävällisen hymyn, sarkastisen virnistyksen ja tietoisen loukkauksen välinen raja saattaa siis olla hämärä. Juhannustanssikeskustelussa hymiöt sekä pehmensivät että kärjistivät esitettyjä väitteitä ja loivat ketjuun sekä keskustelijoiden välistä läheisyyttä että etäisyyttä. Juhannustanssikeskustelun liekehtivää dynamiikkaa ei kuitenkaan voi selittää anonyymiydellä, osallistuivathan käyttäjät siihen omilla, eianonyymeillä Facebook-profiileillaan ja debatti oli avoimesti paitsi heidän ystäviensä, perheenjäsentensä ja tuttaviensa, myös kaikkien muiden halukkaiden luettavissa. Edelleen Deryn ehdottaman affektin latistumisen tai vesittymisen sijaan keskustelua määritti pikemminkin tunneintensiteettien kierto, kasaantuminen ja tihentyminen.

Vaikka verkkoviestintä eroaa kasvokkaisviestinnästä, se ei ole tunnedynamiikaltaan sitä köyhempää tai vähemmän intensiivistä. Muutoinhan voitaisiin väittää, että tekstuaalinen viestintä on itsessään affektiltaan latteaa ja että vaikkapa päiväkirjat, kirjeet, runot tai romaanit tarjoilevat parhaimmillaankin vain hataria tunnekokemuksia. Kirjallista fiktiota arvosteltiin kuitenkin jo 1700-luvulla lukijoiden mielikuvituksen ja aistien kohtuuttomasta kiihottamisesta (Laqueur 2003, 62, 203-204; Hillis 2009, 153). Kirjallisuudentutkija Isobel Armstrongia (2000, 124-125) seuraten tekstien ja lukijoiden kohtaamisten voi sanoa tuottavan yhä uusia affektimuodostelmia, ajatusrakennelmia ja tulkintoja. Tekstit ja lukijat muodostavat keskenään takaisinkytkentäketjuja, joiden energia kasvaa ja vapautuu tulkinnan myötä (emt., 93). Verkkoviestinnässä vastaavat takaisinkytkennät laajenevat affektiivisiksi verkostoiksi, joihin lukeutuvat muun muassa tekstejä lukevat ja kirjoittavat käyttäjät, alustat käyttöliittymäsuunnitteluineen ja informaatioarkkitehtuureineen, niillä tuotettavat ja kierrätettävät tekstuaaliset, visuaaliset ja multimodaaliset viestit sekä niissä syntyvät yhteyden ja etäisyyden aistikokemukset. Huomio siirtyy ja kasautuu verkostoissa samalla kun intensiteetit ja dynamiikat kasvavat ja hiipuvat pois.

Verkkokeskustelujen yksittäiset viestit lukaistaan usein nopeasti lauseiden yli hyppien, eikä ketjuja välttämättä lueta kokonaan. Keskustelualustojen informaatioarkkitehtuuri tukee ja jopa rohkaisee huomion hyppelehtivyyttä säädellessään tapoja, joilla muiden lähettämät viestit ja kommentit tulevat näkyviksi. Facebookissa käyttäjät näkevät seinillä käytävien keskustelujen aloitusviestin tai päivityksen sekä siihen liittyvät uusimmat kommentit. Facebookin informaatioarkkitehtuuri siis kiinnittää käyttäjän huomion ensimmäisiin ja tuoreimpiin kommentteihin sekä kehottaa tätä lisäämään oma kommenttinsa. Halutessaan lukea koko ketjun käyttäjä voi klikata esille 50 kommenttia kerrallaan. Juhannustanssikeskustelu venyi nopeasti satojen kommenttien mittaiseksi, ja siihen myöhemmin liittyneistä todennäköisesti harva kahlasi lävitse koko ketjua: "Mä en 
edes ala lukemaan koko viestiketjua mutta ei tää voi olla oikeesti totta. Pakko olla joku rölli. Tai sitten poliittinen korrektius on mennyt jo aivan liian pitkälle. Ei kukaan oikeasti voi tollaisesta suuttua." (695/164, 1 tykkäys)

Yhtäältä keskustelun katkonaisuus ja terävyys - toistensa ohi puhuvat tai huutavat osallistujat sekä samantyyppisinä ketjun eri vaiheissa toistuvat kommentit - liittyy Facebookin erityispiirteisiin viestintäalustana. Kun yhä uudet osallistujan tarttuivat ensimmäiseen viestiin, keskustelun intensiteetti sekä säilyi että paisui. Toisaalta debatin pirstaloituminen ja esitettyjen näkökulmien polarisoituminen liittyy yleisemmin tekstipohjaisen viestinnän mahdollisuuksiin ja rajoituksiin. Verkkokeskustelijoilla on tilaa tulkita toistensa viestien sävyä, tyyliä, sisältöä ja tarkoituksia sekä kuvitella, millaisia niiden kirjoittajat mahtavat olla. Tämä mahdollistaa nopeat muiden keskustelijoiden tunteita, arvoja ja tavoitteita koskevat yleistykset, minkä juhannustanssidebatissa kierrätetyt "punavihervasemmiston", "suvaitsevaiston", "feministien" ja "persujen" hahmotyypit osoittavat. Puolikas sanakin voidaan lukea laajemman (joskin mahdollisesti piilotellun) agendan, väitteen tai kannan oireena tai todisteena. Reaktiot ja vastaukset kärjistyvät ja inmiset keskustelevat sujuvasti toistensa ohi.

Imogen Tylerin (2006) mukaan inhon ilmaukset vahvistuvat "chaveja" eli työväenluokkaisia brittinuoria käsittelevissä nettikeskusteluissa osallistujien kommentoidessa toisiaan ja tukiessa toistensa näkemyksiä. Seuraten Ahmedin $(2004,195)$ teoretisointia kielestä "vallan muotona, jossa tunteet yhdistävät joitain ruumiita toisiinsa ja liimaavat erilaisia hahmoja yhteen sen mukaan, miten ne liikuttavat meitä" Tyler (2006) esittää, että affekti paitsi elävöittää nopeasti kiihtyviä nettikeskusteluja myös takertuu tiettyihin kommentteihin ja ihmisiin ja jäsentää yksilöiden ja ihmisryhmien välisiä hierarkkisia erontekoja. Tylerin analyysissä tunneintensiteetit tarttuvat nimenomaan nuoreen työväenluokkaan keskiluokkaisen inhon kohteena. Kotimaisissa verkkokeskusteluissa tasa-arvon, sukupuolen, seksuaalisuuden, kansallisuuden, "rodun", etnisyyden ja uskonnollisen vakaumuksen kaltaiset identiteettiasemat herättävät vastaavasti voimakkaita tunteenilmauksia. Maahanmuuton tai turkistarhauksen tapaan nämä aiheet ovat ikään kuin pysyvästi tahmeita, affektein kyllästettyjä.

Juhannustanssikeskustelussa affektin tahmeus ja kierto sekä jäsensi eroja ihmisryhmien välillä että jatkuvasti pirstoi niitä. Eroja vedettiin muun muassa queerien ja eiqueerien klubbaajien, heteronormatiivisten ja ei-heteronormatiivisten keskustelijoiden, sosiaalisen epäoikeudenmukaisuuden ja syrjinnän tunnistavien osallistujien, valkoisten ja ei-valkoisten keskustelijoiden, klubi- ja paritanssikulttuureihin vihkiytyneiden ja niihin vihkiytymättömien, seksin ja huvin motivoimien juhlijoiden, vihreiden ja perussuomalaisten kannattajakunnan, feministien ja ei-feministien, helsinkiläisten ja ei-helsinkiläisten, hauskaa pitävien ja hauskanpitoon kykenemättömien välille. Erontekoja myös kommentoitiin sarkastisesti: "Tämä yhteisö on hyvin sovinistinen, feministinen, fasistinen, rasistinen ym. Ainiin ja tosi niinq persumainen." (525/124, 1 tykkäys)

Juhannustanssiketjun voi nähdä julkisena nimeämisen politiikkaa käsittelevänä keskusteluna. Nettikeskusteluille ominaisella tavalla se kuitenkin johti ketjun edetessä näkökulmien yhä jyrkempään polarisoitumiseen pikemminkin kuin niiden dialogiseen neuvottelemiseen tai tasapainottamiseen (esim. Robinson 2005). Kuten Zizi Papacharissi (2002) 
toteaa, habermasilainen kriittis-rationaalisen vaihdon ja julkisen keskustelun ihanne ei välttämättä sovellu kovinkaan hyvin tunneladattuihin nettikeskusteluihin. Juhannustanssikeskustelu osoittaakin osaltaan, kuinka kerran leimahtaneet avoimet nettidebatit elävät tunneintensiteeteistä pikemmin kuin rationaalisesta argumentaatiosta ja provokaatioista pikemmin kuin neuvotteluhalusta.

Jotkut osallistujat kävivät keskustelua seksuaalivähemmistöjen yhtäläisistä oikeuksista ja syrjivien käytäntöjen sitkeästä näkymättömyydestä, kun taas toisille kyse oli yksittäisten DJ:n väliheitoista ja siten tyhjästä meuhkaamisesta. Siinä missä jotkut keskustelivat yhteiskunnallisista valtasuhteista, toiset keskittyivät klubi-illan tapahtumakulun ja tunnelmien tarkkaan puimiseen - ja yhdet silkkaan välihuuteluun. Näkökulmat vaihtelivat nopean epätahtisesti kommentista toiseen. Joidenkin mielestä kommenttiketju kuvasti heteroiden haluttomuutta tunnistaa oma osallisuuttaan sosiaalisessa syrjinnässä. Toisten mielestä ketju kieli lähinnä herkkänahkaisuudesta ja mielensä pahoittamisesta tilanteessa, jossa kukaan ei ollut loukkausta tarkoittanut. Näistä yhteensopimattomista lähtökohdista käsin keskustelu hyppeli periaatekeskusteluista absurdeihin heittoihin, vähemmän syrjivien klubbauskäytäntöjen kehittelemiseen ja trollaukseen.

\section{Trolleja}

Jos monenlaiset nettikeskustelut pohjaavat tunneintensiteetin rakentumiselle, affektin kierrolle ja tahmeudelle, ei liene järin yllättävää, että keskusteluun osallistuvat pyrkivät tietoisesti vahvistamaan niihin liittyvää objektien ja merkkien kiertoa. Vihamielisyyden ja myötämielisyden ilmaukset, huvittuneisuuden aallot, etäännytetty sarkasmi, loukkaantumisen ja haitan kuvaukset kiinnittävät tahmeudessaan lukijoiden huomion ja houkuttelevat heitä seuraamaan keskustelun kehitystä. Trollaus liittyy olennaisesti keskustelujen tahmeuteen ja intensiteetin rakentumiseen. Trollauksesta keskustellaan julkisuudessa usein nettiraivon ja vihapuheen sukuisena kielteisenä häiriötekijänä. Adi Kuntsman puolestaan näkee trollauksen moninaisena ja ristiriitaisena käytäntönä, joka voi sekä yhdistää että pirstoa verkkoyhteisöjä (emt., 101-102; myös Herring ym. 2002).

Trolli saattaa esittää muiden viestijöiden kannoista voimakkaastikin poikkeavia näkemyksiä, teeskennellä yksinkertaisuutta tai olla piinallisen kirjaimellinen. Toiminnan pyrkimyksenä on provosoida ja häiritä sekä yksittäisiä keskustelijoita että yleisempää debattia ja sitä kautta viihdyttää sekä trollia itseään että muita ketjuun osallistuvia (ks. Phillips 2013; Milner 2013; Higgin 2013). Trolli tarvitsee yleisöä todistamaan provokaatioidensa onnistumista: tässä mielessä trollaus on sosiaalista, esityksellistä sekä pelimäistä toimintaa (Wilson, Fuller \& McCrea 2013). Trollauksen mahdollinen nautinto piilee keskustelun affektin vahvistamisessa, ja sitä voi pitää toiminnan olennaisena motivaationa ja päämääränä. Käyttäjät, jotka eivät itse trollaukseen sorru ja jotka saattavat sitä paheksuakin, voivat yhtälailla nauttia tunneintensiteettien paisumisesta trollien provokaatioiden myötä. Kyse ei ole niinkään Grusinin luonnostelemasta positiivisen affektin optimoinnista, vaan toisiaan vahvistavista ja vaihtelevista tunneintensiteeteistä, jotka liikuttavat käyttäjiä ja ajavat keskusteluja eteenpäin. On syytä huomioida, etteivät nettikeskuste- 
lujen tai sosiaalisen median sovellusten ilot ylipäätään välttämättä liity vain viestinnän sisältöihin, vaan yhtälailla niiden tyyleihin, sävyihin ja intensiteetteihin. Käyttäjien loukkaantuessa tai huvittuessa, kommentoidessa viestejä tai jakaessa linkkejä keskustelun ja kyseisen alustan - hetkellinen tahmeus kasvaa.

Trollit astuivat juhannustanssikeskusteluun heti sen kolmannessa kommentissa, jonka laati yksi klubi-illan DJ:stä. Kommentti oli sitaatti Pave Maijasen vuoden 1984 iskelmästä "Lähtisitkö": "Lähtisitkö silloin kanssani järvelle? Sulle sukeltaisin helmen valkean. Istuisitko kanssani keskipenkille, vastaisitko hellään suudelmaan?" (3/3, 7 tykkäystä). Reaktiona kahteen ensimmäiseen, sävyltään leimallisen vakavaan puheenvuoroon kommentti oli leimallisen absurdi. Trolli kuitenkin onnistuu vain muiden reagoidessa tämän yritykseen, eikä tämä yritys saanut muissa vastakaikua. DJ koettikin pian uudelleen: "Aion tänään kehottaa kukkamekkoja ja samettihousuja nussimaan toisiaan!" (6/3, 28 tykkäystä). Kukaan ei tarttunut myöskään tähän yritykseen, mutta DJ ei luopunut keskustelusta.

Tää keskustelu nyt on viimeistään osoittanut, että kaikki eivät todellakaan ole tervetulleita we love helsinkiin (menkää homoklubeillenne siitä, dj:n transihmisiä pilkkaavat kommentit keskustelussa). - - tärkeintä tietysti olisi että jos joku nostaa esille ongelmallisia valtakäytäntöjä (kuten dj-spiikit) niin ei tarvitsisi pelätä tällaista seksististä ja homofobista vastahyökkäystä ja naurettavaksi tekemistä. Alistavat ja normeja ylläpitävät käytännöt eivät tietenkään aina ole intentionaalisia (eli tarkoituksella tehtyjä), mutta se ei tee niistä vähemmän vahingollisia - - (214/29, 22 tykkäystä)

Näitä vuodatuksia lukiessani on otsaan kasvanut kyrpä, jolla aion nussia miehiä perseen reikään niin että koko ylävartaloni muuttuu ruskeaksi. (215/3, 12 tykkäystä)

Tämä DJ:n esittämä kommentti määriteltiin homofobiseksi (234/1), toivottomaksi (221/29) ja todella halventavaksi (280/7). DJ puolestaan syytti muita keskustelijoita homofobiasta (409/3). Kaikki yhteisöt - sekä netissä ja muualla - edellyttävät jonkinlaista, tiukempaa tai löyhempää sisä- ja ulkopuolisuuden määrittelyä, sillä ryhmäjäsenyys määrittyy suhteessa sen ulkopuolelle jäävään (Joseph 2002). Trolli tekee tällaisen rajanvedon näkyväksi. Toimimalla ryhmän jaettuja oletuksia vastaan ja rikkomalla oletettua konsensusta trollit voivat myös pakottaa ryhmän määrittelemän omia sääntöjään ja normejaan (vrt. Dibbel 1993). Juhannustanssikeskustelun keskeinen jännite liittyi We Love Helsinki -kollektiivin ja heteronormatiivisuuden suhteeseen: siihen, kuinka avoimia sen tapahtumat ovat muille kuin heteroseksuaalisille juhlijoille.

Pahoittelut etten ole We Love Helsingin toiminnanjohtajana ja Juhannustanssien järjestäjänä kommentoinut aiemmin, mutta tässä tapahtumajärjestämisessä on hieman muutakin hommaa kuin facebookissa roikkuminen ja eilen ja tänään olen pitänyt mielestäni ansaittua vapaapäivää, enkä ole edes tietokonetta avannut ennen tätä. Haluan pahoitella kaikille jotka ovat pahoittaneet mielensä välispiikkien vuoksi. We Love Helsingin tanssit ovat kaikille avoimia ja kaikki ovat niihin tervetulleita. (188/16, 15 tykkäystä) 
Hei Maria, pahoittelut etten taaskaan ehdi vastaamaan kaikkiin kysymyksiisi, sillä olen parhaillaan soittamassa levyjä - - ja jatkan täällä puoli kahteen asti. Jos kaipaat vastauksia kysymyksiisi todella kipeästi heti tänään, niin voit soitella minulle numerooni - - toivoisin, että jos jollekin on vielä jäänyt jotain hampaankoloon välispiikeistä, epäselväksi WLHtansseista tai muusta niin voisitte soittaa minulle ja voin vastata kaikkiin mahdollisiin kysymyksiin. (193/16, 23 tykkäystä)

- - On se kumma, jos et yhtään ymmärrä lukemaasi. Minä en ole pahoittanut mieltäni, tässä ei ole siitä kysymys. Täytyykö se toistaa vielä monta kertaa? Tässä on kyse suuremmista asioista, toimintatavoista ja asenteista. Ihmettelen että WHL-brändin toiminnanjohtajalla on varaa olla sanoutumatta irti homofobisuudesta ja olla antamatta kunnon vastinetta. Ihmettelen ettei toiminnanjohtaja voi kuvitella ottavansa kantaa asiaan lomallansa, ellei sitten lennä avaruuteen, jossa netti ei toimi. Minua ei kiinnosta henkilökohtainen keskustelu kanssasi. Kuten sanoin, kyse ei ole henkilökohtaisesta asiasta. Olisin luullut, että näin ison tapahtuman ja tapahtumien (!) järjestäjä tuntisi vastuunsa. Viesti minusta on, ettei WHL:ää kiinnosta kuin enemmistön miellyttäminen. Surullista. (196/1, 9 tykkäystä)

Korhosen terävät vastaukset herättivät muissa keskustelijoissa yhä uusia kannanottoja ja debatin tunnelataus säilyi päivästä toiseen. Ketju oli jo alkanut elää omaa elämäänsä siinä vaiheessa, kun WLH:n toiminnanjohtajan lähetti linkin kollektiivin Facebook-sivuilla julkaisemaansa muistiinpanoon, jonka mukaan "We Love Helsinki ei hyväksy homofobiaa, rasismia tai mitään muutakaan ihmisryhmään tai yksilöihin kohdistuvaa syrjintää ja sanoutuu irti kaikesta seksuaalisen suuntautumisen, ihonvärin tai millä tahansa muulla perusteella tapahtuvasta syrjinnästä. We Love Helsinki toivoo kaikilta tapahtumiin ja keskusteluun osallistuvilta muut ihmiset huomioon ottavaa hyvää käytöstä ja suvaitsevaisuutta kohdata erilaisuutta avoimesti." (569/16, 6 tykkäystä) Tässä vaiheessa keskustelijoiden väliset liittoumat olivat jo sattumanvaraisia, eivätkä hyvä käytös tai erilaisuuteen kohdistuva suvaitsevuus suinkaan olleet vallitsevia periaatteita.

Jo ketjun lyhyen elinkaaren varhaisvaiheessa keskustelija ehdotti siirtymistä yhdessä eteenpäin mahdollisimman monille osallistujille mukavien tapahtumien luomiseksi (37/14). Korhonen vastasi näihin näkökantoihin kärkevästi: "Olisi varmaan pitänyt tehdä ensiksi katumusharjoituksia ja sitten lähettää kirjallinen anteeksipyyntö järjestäjälle, että osallistuin tapahtumaan. Taisi tulla kylvettyä nyt vaan pahaa verta tällaisilla itsekkäillä huomioilla vaikka pitäisi mennä 'yhdessä eteenpäin' ja 'positiivisella asenteella'." (87/1, 3 tykkäystä) Keskustelun jatkuvasti kärjistyessä viittaukset yhteisöllisyyteen olivat ymmärrettävän ambivalentteja. WLH:ta arvosteltiin yhteisöllisyyden periaatteidensa vastaan toimimisesta samalla kun sitä kiitettiin yhteisöllisyyden luomisesta (143/37, 190/1, 280/7). Ketjun nähtiin jopa kehkeytyvän omaksi (trolli)yhteisökseen (372/28). Aggressiiviset kommentit haittasivat jatkuvasti yrityksiä saavuttaa konsensus ja trollien ja ei-trollien retoriset taktiikat olivat hyvin samankaltaisia: "mä en erota tästä keskustelusta trolleja inmisistä jotka ovat 'tosissaan'. sen verran absurdi on tämä koko ketju, 
ugh." (417/104, 4 tykkäystä). Korhonen itse nähtiin trollina ja häntä onniteltiin koko keskustelun käynnistäneestä taidokkaasta provosoinnista:

Trollausarvoltaan toki eeppinen! (277/61, 7 tykkäystä)

Tästä pitäisi oikeasti antaa jo palkinto keskustelun aloittajalle. Näin menestyksekästä trollia ei mahdollisesti ole nähty koko internetin historiassa. (377/28, 5 tykkäystä)

Ihan hyvä keskustelun avaus. Kirvoittanut jo yli 400 kommenttia ja liekit lyövät yli seinien. :) Parasta viihdettä sitten Top Gunin, jossa Maverick ei hakenut Icemania tanssimaan vaikka olisi halunnut. (395/99, 4 tykkäystä)

Trollausviittauksia viljeltiin halki ketjun, joka nimettiin vuoden Trolli-Finlandia -kisan ennakkosuosikiksi (111/3, 265/52, 711/170: WLH-ketju valikoituikin vuoden 2012 finaaliin, jonka voiton vei yhteiskunnallisesti aktiivinen keskustelija, dosentti Johan Bäckman). Neljäntenä keskustelupäivänä aktiivisiin osallistujiin viitattiin jo trolleina: "Oho, trollitkin alkaa jo väsyä. Haukotuttaa. Koittakaahan pojat, vielä kerran." (414/6o, o tykkäystä) Keskustelijoiden sukupuolittaminen pojiksi kertoo osaltaan siitä, että heteronormatiivisuuden kritiikkejä kyseenalaistivat terävimmin heteromiehiksi määrittyneet osallistujat.

\section{Ilonpilaajia ja meemejä}

Vaikka enemmän tai vähemmän sattumanvaraiset provokaatiot jatkuivat koko ketjun elinkaaren ja lisääntyivät sen loppua kohti, eivät keskustelijat juurikaan tarttuneet niihin. Trollausyrityksistä ei siis tullut tahmeita. Useimmat kommentit kiinnittyivät Korhosen kirjoituksiin ja nimenomaan hänestä tuli keskustelun tahmea keskus, johon myös näyttävimmät hyökkäykset kohdistuivat. Korhosta syytettiin sekä haluttomuudesta pitää hauskaa että halusta tietoisesti pilata muiden huvi. Korhoselle taas kyse oli huvittelun poissulkevuudesta ja happamaksi muuttuneesta huvista:

Relatkaa ja pitäkää hauskaa, sehän on koko tapahtuman tarkoitus :) (10/7, 46 tykkäystä)

- - onko relaus-kehotuksen tarkoitus kentien vähätellä asiaa ja pyrkiä lopettamaan keskustelu aiheesta? Hauskanpito ei onnistu kaikilta samalla tavalla jos nämä suljetaan spiikeillä ulos. Sinua hauskanpitoasi muiden ulossulkeminen ei kuitenkaan taida haitata, koska haluat että keskustelu aiheesta ohitetaan. Jos haluat "pitää hauskaa", nin ei ehkä kannata sitten lukea näitä kommentteja, jos ne eivät kuulu sinun hauskan pitoosi :). Antajsit muiden kuitenkin keskustella. (11/1, 14 tykkäystä)

Aina noiden "yhyy heteronormatiivisuus nyyh"-tyyppien pitää pilata kaikki enemmistöjen huvit. Menkööt tanssimaan LGBT-paikkoihin, jos herkkä mieli ei kestä tuollaista. (12/8, 9 tykkäystä) 
Ahmed (2012 ei sivua) nimeää "feministisiksi ilonpilaajiksi" (feminist killjoys) ne, jotka "kieltäytyvät nauramasta oikeissa kohdissa" ja ovat "haluttomia istumaan alas onnellisuuden pöytään". Ilonpilaajat kieltäytyvät liittymästä leikkiin, joten heidän nähdään pilaavan ilmapiirin ja tekevän muiden olon epämukavaksi (Ahmed 2010b, 69). Viestiketjussa ja sitä koskevissa kommenteissa ilonpilaajiksi nimettiin sekä Korhonen ja seksuaalivähemmistöt että feministit ja punavihervasemmistolainen suvaitsevaisto. Korhosen voi myös nähdä omaksuneen strategisen ilonpilaajan aseman "hankaluuksien synnyttäjänä, toisinajattelijana, ilon tappajana" (emt., 17) kieltäytyessään tulemasta iloiseksi tai omaksumalla muiden keskustelijoiden ehdottamaa myönteistä asennetta. Hänen vastauksensa muiden (sekä dialogisiin että hyökkääviin) kommentteihin olivat leimallisen tylyjä: "haluaisin tietää kuulutko sinä debiili-kerhoon, vai oletko muuten vain tyhmä" (33/1, 20 tykkäystä); "Toivottavasti ryhdistäydyt ja kasvatat selkärangan, kun vähän kasvat" (90/1, 5 tykkäystä); "Tuo sinun kommenttisi syrjii nyt kyllä kaikkea älyllistä toimintaa maan päällä" (109/1, 8 tykkäystä). Sekä Korhosen esittämää kritiikkiä, esitystyyliä että muihin keskustelijoihin kohdistuneita heittoja arvosteltiin: "Ja aivan turha vinkua että aloitusviesti oli vain neutraali tiedustelu tilaisuuden luonteensta, kun kenelle tahansa perussisälukutaidon omaavalle on päivän selvää että tappelemaan tänne on tultu. Sait juuri 15 minuuttiasi, toivottavasti oli sen arvoista." (647/148, 8 tykkäystä). Seuraava katkelma kuvastaa ketjun keskustelutyyliä:

Pienet asiat ovat isoja asioita. Ne, joita nyt väität pieniksi asioiksi, eivät kuitenkaan ole pieniä asioita, vaan ne ovat isoja asioita. Olemassa olevien epätasa-arvoisten valta-asetelmien tukeminen ja ylläpitäminen on hyvinkin merkittävä asia. Sokeus sortaville käytännöille ja niiden sivuuttaminen on myös iso asia. Vähiten vapaa on se, joka kuvittelee olevansa tällaisten rakenteiden ulkopuolella. (250/1, 8 tykkäystä)

Vastapuolen haukkuminen homofobisiksi rasistipersuiksi ainakin edesauttaa tosi paljon keskustelua. (251/26, 45 tykkäystä)

- - Pienistä asioista tulee isoja asioita kun ne siirtää väärään kontekstiin. Kukaan meistä ei ole täällä sivuuttamassa "sortavia käytäntöjä" enkä ainakaan itse kuvittele olevani kenenkään yläpuolella. Ethän tahallasi sivuuta pointtiani? Ku en osaa enää tämän selkeämmin sanoa mitä tarkoitan ilman että kuulostan loukkaavalta. (252/46, 20 tykkäystä)

- - uskon että et ole ymmärtänyt koko pointtia, enkä tosiaan jaksa selittää enää asiaa. $(253 / 1)$

Ketjun tunnedynamiikka kiertyi Korhosen ympärille ja häntä koskevat kommentit kehkeytyivät yhä terävämmiksi ja henkilökohtaisemmiksi. Korhosta syytettiin muiden vähättelystä ja aliarvioinnista, nimiteltiin miesvihaajafeministiksi (391/96), huomiohuoraksi (688/160) ja huomionkipeäksi narsistiksi, jonka ajatukset ovat fasistisia (661/150) ja jota luonnehtii "kaikenlainen passiivis-aggressiivinen hiekkapilluilu, pätemisen tarve, kritiikin esittäminen kritiikin esittämisen takia, muka-akateeminen nero- 
patteilu ja yleisesti arvostetun ideologian käyttö tekosyynä ja suojakilpenä omaan käytökseen liittyvän arvostelun torjunnassa." (383/45, 26 tykkäystä) Joidenkin keskustelijoiden mielestä tällainen hyökkäävyys ei jättänyt muuta vaihtoehtoa kuin itsepuolustuksen (675/15), kun taas toisten mielestä Korhonen sai vain ansionsa mukaan (696/165).

Tylerin (2006) mukaan nettikeskustelujen inhon ilmaukset vahvistavat hierarkkisia sosiaalisia erontekoja. Juhannustanssikeskustelussa eroja piirrettiin poliittisten rintamalinjojen, sukupuolen, koulutustaustan ja kulttuurisen pääoman mukaan, mutta kääntämällä Tylerin kuvailema luokkahierarkia osin päälaelleen. Heteronormatiivisuuden kaltaisia akateemisia termejä viljeleviä osallistujia syytettiin itsensä nostamisesta muiden yläpuolelle. "Onkohan joku nyt lukenu vähän liikaa Foucaultia? Hienoa että asioita nostetaan esille ja niistä puhutaan, mutta COME ON. Tommoinen aloituksen tapainen ylimieliseksi tulkittava nokittelu (tai silkka $v^{\star \star *} \mid u$ ) ja ihmisten "persuttelu" on varmasti iso syy sille, miksi vihreillä on vähän - - maine." (616/146, 11 tykkäystä) Kaiken kaikkiaan keskustelijat eivät hyökänneet "tyhmiä kusipäitä" vastaan, kuten Tylerin tutkimusaineistossa, vaan niitä vastaan, joiden nähtiin leimaavan muita tyhmiksi kusipäiksi:

Jos joku osaa ottaa takaraivoon, on ylimielisyys "tyhmiä" kohtaan. Tässä ketjussa viljellään sivistyssanoja ja oletetaan kaikkien olevien sivistyneitä ajattelievia hahmoja. Jos ei tajunnanvirta aukea tai ei ymmärretä kuinka maailma pelastuu oikeita sanoja käyttämällä, olet "persu" eli ylimielisesti itseään vähän tyhmempi. Näinhän ei todellakaan pitäisi olla tasa-arvon vaatijoilta. Vaatimalla muita käyttämään tiettyjä sanoja ja puuttumalla kielenkäyttöön, asettaudumme muiden yläpuolelle. (718/86, 3 tykkäystä)

Korhosesta muokkautui nopeasti sekä akateemis-feministisen ilonpilaajan että mielensäpahoittajan virtuaalinen ruumiillistuma. Keskustelijat jakoivat häntä koskevia hakutuloksiaan, spekuloivat hänen poliittisella toiminnallaan ja seksuaalisella suuntautumisellaan. Hänestä jopa rakennettiin eräänlaista meemiä: "Pakko arvostaa ihan papukaijamerkin arvoisesti. Mariasta tuli meemi, siihen eivät kaikki yllä" (299/75, 13 tykkäystä). Meemeillä - joita jotkut nimittävät kulttuuriksi geeneiksi - tarkoitetaan netissä viraalisesti, tartunnan kautta leviävää sisältöä, josta osa poistuu kierrosta nopeasti ja osa taas kiinnittää tahmeudessaan käyttäjien mielenkiintoa vuodesta toiseen (Shifman 2013). Olkoon kyseessä väärinkirjoitettu sana, television kuvavirrasta napattu GIF-animaatio, hassu kotivideo tai piirretty kuva, meemi syntyy kierrätyksestä ja saa elinvoimaa käyttäjien laatimista kommenteista, variaatioista, tribuutti- ja parodiaversioista. Meemit liikkuvat ja tarttuvat sosiaalisten yhteyksien kautta samalla sekä kasaantuen että muuttuen (Shifman 2012, 188-189; Milner 2013). Helppokäyttöiset meemien varioimiseen ja levitykseen keskittyvät verkkoalustat, kuten Quick Meme ja Meme Generator kielivät osaltaan meemituotannon suosiosta sekä meemien määrän ja volyymin räjähdysmäisestä kasvusta.

Meemejä - linkitettyjä kuvia ja videoita tai viittauksia - käytetään verkkokeskusteluissa vihjeinä, kommentteina, toteamuksina ja arvostelmina. Esimerkiksi linkki You- 
Tubessa levitettävään, vuoden 1976 neuvostoliittolaisesta televisio-ohjelmasta napattuun videoklippiin nimeltä "Trololo" on vihje siitä, että joku keskustelijoista koettaa trollata tai on jo onnistunut siinä. Vaihtoehtoisesti kyseessä voi olla yritys provosoida, alleviivata tai korostaa keskustelun absurdiutta. Trololo-meemilinkki jaettiin jo juhannustanssikeskustelun varhaisessa vaiheessa (38/15, viestinä "Trolololo. Trolled", 19 tykkäystä). Vastaavasti viittaus meemiin "First World Problems" eli "Kehittyneiden maiden ongelmat" antaa ymmärtää, että esitetty valitus, pähkäily tai kritiikki edustaa etuoikeutetun lännen asukkaiden triviaaleja ja globaalissa mittakaavassa arvioituna merkityksettömyydessään koomisia murheita. First World Problems -viittausta käytettiin leimaamaan juhannustanssikeskustelu yliherkkien mielensäpahoittajien ylireagoinniksi, josta uupui niin oikea mittakaava kuin kohtuullisuuden tajukin (44/108, 535/128, 541/127). Tapahtuma myös innoitti ainakin kaksi variaatiota kyseisestä meemistä.

Meemit toimivat juhannustanssikeskustelussa sekä etäännyttämisen välineinä että metatasoisina, ketjun luonnetta ja painotuksia koskevina kommentteina: "Trololo" auttoi leimaamaan koko keskustelun onnistuneeksi trollaukseksi kun taas "First World Problems" kehysti heteronormatiivisuuden kritiikit triviaaliksi rutinaksi. Molempien meemien käyttö pyyhki osaltaan näkyvistä keskustelun monipolvisuutta ja monisyisyyttä määritellessään sitä yksittäisten, kärjistettyjen piirteiden kautta. Queer-feministiseksi ilonpilaajaksi asemoitu Korhonen puolestaan yhdistettiin ylenpalttiseen ärsyyntyneisyyteen, yliherkkyyteen ja ylimitoitettuun kriittisyyteen:

Kiitos ja kumarrus työpäivän piristämisestä. Huikeaa ammattiloukkaantumista viestiketjun aloittajalta. propsit! =) (533/127, 2 tykkäystä)

huhhuh, kylläpäs nykyään osataankin pahoittaa mieli asiasta kuin asiasta. taitaa ongelmana olla enemmän homofobiafobia kuin homofobia. :) (648/158, 1 tykkäys)

Eiköhän heikkohermoiset ammattiloukkaantujat Korhonen tai - - pian tule kertomaan, mitä vikaa tässäkin lausunnossa on? Jotenkin sen on pakko syrjiä jotain. Näin ei voi olla! (Viesti WLH:n seinällä, 27.6.2012, 8 tykkäystä)

Korhosta hahmoteltiin paitsi trollina ja meeminä, myös WLH:n markkinointiluomuksena, jonka antaa juhannustansseille lisänäkyvyyttä:

Itse luulen, että Korhosen profilin on luonut WLHn markkinoinnista vastaava taho, ja pakko todeta, että kyseessä on varmasti nero. Nyt WHL saa ilmaista mainosta, ja ensi vuoden tanssit ovat varma menestys. Persut tulevat paikalle koska ajattelevat "nää on ne tanssit missä ei homoja ja ulkomaanpellejä suvaita" ja homot tulevat sankoin joukoin paikalle vaatimaan oikeuksiaan. Jos nyt sattuisi olemaan niin, että on olemassa ihmisiä, jotka eivät jostain syystä kuulu kumpaankaan ryhmään, niin kyseiset henkilöt varmaan saapuvat paikalle koska tiedossa on hyviä myllyjä. Lisäksi, median ansiosta kaikenmaailman Kehä IIIn ulkopuolella asuvat heinähatutkin ovat kiinnostuneet tapahtumasta. (484/118, 14 tykkäystä) 
Meemit olivat yksi olennainen säde juhannustanssikeskustelun intertekstuaalisessa punoksessa, jossa viittailtiin sekä Tuomas Kyrön Mielensäpahoittajaan (107/24, 666/151) että Hannu Salaman Juhannustanssien herättämään kohuun (119/26, 122/26, 301/58, 496/121, 499/81) sarkastisina analogioina. Linkit juhannustanssikeskustelua käsitteleviin uutis- ja blogijuttuihin kiersivät, samoin esimerkiksi linkit M.A. Nummisen Juhannusbluesiin (724/101), Helsingin Sanomien artikkeliin "Luomuruoka tekee omahyväiseksi" (723/155), ylilyövää poliittista korrektiutta kommentoivaan videoklippiin (702/166), Lolcats-kuvaan (685/84) ja Wikipedian rasismi-termin määritelmään (670/155), jonka varassa Korhosta määriteltiin rasistiksi.

\section{Epävakaa tahmeus}

Nettikeskustelujen tunneintensiteetin roihahtavat hetkessä liekkeihin, mutta myös hiipuvat nopeasti, mikäli uudet huomion vangitsevat ja vastaamaan provosoivat viestit eivät pidä yllä niiden poltetta. Juhannustanssikeskustelu ei ehtinyt hiipua Korhonen poistettua sen äkillisesti. Tapahtumasta keskusteltiin Facebook-seinillä vielä pari päivää, mutta kun kommentit eivät enää kiertäneet, ei debatin tahmeudesta jäänyt paljoakaan jäljelle.

Verkkokeskustelujen kärjistyminen debateiksi liittyy yhtäältä niiden käsittelemiin teemoihin. Esimerkiksi feminismi ja seksuaalivähemmistöjen oikeudet ovat yhteiskunnalliseen tasa-arvoon liittyviä kysymyksiä, joista useimmilla on jonkinlaista arkikokemusta ja näkemystä. Teemoihin keskittyvässä keskustelussa provosointi on helppoa (vrt. Milner 2014) ja debatti voi nopeasti karata polarisoituneeksi huuteluksi. Näin oli myös juhannustanssikeskustelun kohdalla. Debatin kärjistymistä on kuitenkin tarpeen selittää keskusteluteemojen ja kontekstien erityisyyden lisäksi myös verkkoviestinnän yleisemmällä dynamiikalla - tavoilla, joilla nettikeskustelujen intensiteetit kasvavat, kommentit kärjistyvät, tunteet roihahtelevat ja muiden keskustelijoiden persoonasta tehdään vikkeliä ja reippaita johtopäätöksiä. Verkkoviestinnän nopeus on tämän affektiivisen dynamiikan erottamaton elementti, joka liittyy myös nettialustojen rajoituksiin, mahdollisuuksiin ja erityispiirteisiin. Kuten olen edellä esittänyt, Facebookin informaatioarkkitehtuuri ruokki osaltaan juhannustanssikeskustelun katkonaisuutta tavoillaan tarjota käyttäjien kommentteja muiden nähtäväksi, tykättäväksi tai torjuttavaksi.

Juhannustanssikeskustelun analysointi auttaa havaitsemaan, että 1990-luvulla esitetyt diagnoosit verkkoviestinnän kasvottomuuden ja nimettömyyden vaikutuksesta keskustelujen aggressiivisiin ja teräviin sävyihin ovat sekä valideja että osittaisia. Vaikka Facebook ei ole palveluna nimetön, siinä käydyt keskustelut voivat - etenkin ystäväverkostoja avoimemmilla ja julkisilla alueilla, kuten WLH:n tapahtumasivulla roihahtaa hyvinkin intensiivisiksi. Tekstipohjaisen nettiviestinnän erityisyydet, kuten mahdollisuus selata viestiketjua nopeasti kommentista toiseen hyppien, niitä kursorisesti lukien ja tehden nopeita päätelmiä muiden keskustelijoiden taustaoletuksista, arvoista ja näiden tarkoituksista, ruokkivat osaltaan tätä intensiteettiä. Ironia, sar- 
kasmi ja monimerkityksellisyys sekä elävät että katoavat nettikeskustelujen kärjistyessä, käyttäjien tarttuessa toisten sanoihin ja kehystäessä omiaan hymiöillä.

Nettikeskustelujen tunneintensiteetti vetoaa ja häiritsee, viehättää ja inhottaa, vetää lähelle ja sysää taas luotaan. Käyttäjät provosoivat toisiaan tietoisesti trollaten, mutta heidän muotoilunsa ja näkemyksensä voivat myös tahattomasti kiihdyttää muita teräviin kannanottoihin. Tämä ilmeni juhannustanssikeskustelun nopeassa lainehdinnassa pohdiskelevista kommenteista syyttelyihin, puolusteluihin ja huuteluihin. Keskustelijoiden ei tarvitse odottaa puheenvuoroa, vaan he reagoivat nopeasti ja usein toistensa kanssa ristiin. Tämä aaltoilu ei ole kenenkään yhden keskustelijan hallittavissa. Keskenään riitelevien ja tyyliltään eroavien argumenttien välinen liike liittyy myös nettiselaamisen yleisempään dynamiikkaan: jatkuvaan klikkailuun, liikkeeseen sivulta, sivustolta, videosta ja linkistä toiseen. Käyttäjä hakee levottomalla liikkeellään jotain, joka vangitsisi hänen huomionsa ja koskettaisi häntä, vaikka sitten kuinka lyhyeksi aikaa (vrt. Dean 2010). Juhannustanssikeskustelusta kasvoi yksi tällainen kiinnekohta, affektein kyllästetty tilapäinen huomion tiivistymä, jossa kriittinen keskustelu, viihteellinen huutelu, provosointi, turhautuminen, kiihtymys ja etäännytetty sarkasmi niveltyivät orgaanisesti toisiinsa.

\section{Viitteet}

1 Timo Santalan perustama We Love Helsinki on järjestänyt tanssiklubeja vuodesta 2008. Juhannustanssien lisäksi tapahtumalistalla ovat olleet mm. Vapputanssit ja Uuden Vuoden Tanssit. Tanssiklubien musiikki koostuu vanhasta 1930-1980-lukujen iskelmämusiikista ja niissä on voimassa sekahaku.

2 Nettitutkimuksen ja affektitutkimuksen yleisemmistä yhteyksistä ks. Paasonen, Hillis ja Petit ilmestyy.

3 Lämpimät kiitokseni Julia Koivulanaholle ja Aino Harvolalle heidän avustaan tutkimusaineiston koostamisessa ja erittelemisessä.

4 Lukija saattaa tässä kohtaa kysyä, miksei myös tapahtumaa ja sitä kautta sen järjestäjää ei ole anonymisoitu, sillä vaikka varsinainen keskustelu on poistettu, sen jäljet ovat helposti löydettävissä blogeista ja netin uutisarkistoista. Maria Korhosen anonymiteetti on siten horjuva. Olennaisin syy on se, että koko tapahtuman anonymisointi vaikuttaisi kovin keinotekoiselta. Käyty Facebookkeskustelu oli julkinen mediatapaus, joka ei rajautunut millekään tietylle nettifoorumille ja tapahtuman anonymisoimattomuus auttaa sen yleisen kontekstin hahmottamisessa. Ratkaisuuni vaikuttaa myös se, ettei Korhonen itse ole pitänyt anonymisointiaan välttämättömänä. Santala puolestaan ei halunnut itseään anonymisoitavan.

\section{Kirjallisuus}

Ahmed, Sara (2004). The Cultural Politics of Emotion. Edinburgh: Edinburgh University Press.

Ahmed, Sara (2010a). Creating disturbance: Feminism, happiness and affective differences. Teoksessa: Liljeström, Marianne \& Paasonen, Susanna (toim.). Working with Affect in Feminist Readings: Disturbing Differences. London: Routledge, 33-46.

Ahmed, Sara (2010b). The Promise of Happiness. Durham: Duke University Press.

Ahmed, Sara (2012). A willfulness archive. Julkaisematon keynote-alustus, gth Crossroads in Cultural Studies Conference, Pariisi 2.7.2012.

Armstrong, Isobel (2000). The Radical Aesthetic. Oxford: Blackwell.

Coté, Mark \& Pybus, Jennifer (2007). Learning to immaterial labour 2.0: MySpace and social networks. Ephemera: Theory Q Politics in Organization 7: 1, 88-106. 
Dean, Jodi (2010). Blog Theory: Feedback and Capture in the Circuits of Drive. Cambridge: Polity

Dery, Mark (1994). Flame wars. Teoksessa: Dery, Mark (toim.). Flame Wars: The Discourse of Cyberculture. Durham: Duke University Press, 1-10.

Dibbell, Julian (1993). A rape in cyberspace. Village Voice 38: 51, 36-42.

Grusin, Richard (2010). Premediation: Affect and Materiality After 9/11. New York: Palgrave.

Hafner, Katie \& Lyon, Matthew (1996). Where the Wizards Stay up Late: The Origins of the Internet. New York: Simon \& Schuster.

Herring, Susan; Job-Sluder, Kirk; Scheckler, Rebecca \& Barab, Sasha (2002). Searching for safety online: Managing "trolling" in a feminist forum. The Information Society 18: 5, 371-384.

Higgin, Tanner (2013.) B/lack up: What trolls can tell us about race. Fibreculture 22. Saatavilla: http:// twentytwo.fibreculturejournal.org/fcj-159-black-up-what-trolls-can-teach-us-about-race/ (luettu 9.9.2014).

Hillis, Ken (2009). Online a Lot of the Time: Ritual, Fetish, Sign. Durham: Duke University Press.

Joseph, Miranda (2002). Against the Romance of Community. Minnesota: Minnesota University Press.

Karppi, Tero (2014). Disconnect.me: User Engagement and Facebook. Turku: Turun yliopiston julkaisuja, sarja B, osa 376, Humaniora.

Kuntsman, Adi (2007). Belonging through violence: Flaming, erasure, and performativity in queer migrant community. Teoksessa: O’Riordan, Kate \& Phillips, David J. (toim.). Queer online: Media, Technology Q Sexuality. New York: Peter Lang, 101-120.

Laqueur, Thomas (2003). Solitary sex: A Cultural History of Masturbation. New York: Zone Books.

Milner, Ryan M. (2013). Hacking the social: Internet memes, Identity antagonism, and the logic of the lulz. Fibreculture 22. Saatavilla: http://twentytwo.fibreculturejournal.org/fcj-156-hacking-the-socialinternet-memes-identity-antagonism-and-the-logic-of-lulz/ (luettu 9.9.2014)

Paasonen, Susanna (2011). Carnal Resonance: Affect and Online Pornography. Cambridge: MIT Press.

Paasonen, Susanna; Hillis, Ken \& Petit, Michael (ilmestyy). Introduction: Networks of transmission: Intensity, sensation, value. Teoksessa: Hillis, Ken; Paasonen, Susanna \& Petit, Michael (toim.). Networked Affect. Cambridge: MIT Press, 1-24.

Papacharissi, Zizi (2002). The virtual sphere: The Internet as public sphere. New Media and Society 4: 9, 9-27.

Phillips, Wendy (2013). The house that Fox built: Anonymous, spectacle, and cycles of amplification. Television and New Media 14: 6, 494-509.

Robinson, Laura (2005). Debating the events of September 11th: Discursive and interactional dynamics in three online fora. Journal of Computer-Mediated Communication 10: 4. Saatavilla: http://onlinelibrary. wiley.com/doi/10.1111/j.1083-6101.2005.tboo267.x/full (luettu 24.2.2014).

Shifman, Limor (2012). An anatomy of a YouTube meme. New Media Q Society 14: 2, 187-203.

Shifman, Limor (2013). Memes in Digital Culture. Cambridge: MIT Press.

Tyler, Imogen (2006). Chav scum: The filthy politics of social class in contemporary Britain. M/C Journal 9: 5. Saatavilla: http://journal.media-culture.org.au/o610/og-tyler.php (luettu 24.2.2014).

Wallace, Patricia (1999). The Psychology of the Internet. Cambridge: Cambridge University Press.

Walther, Joseph B. \& D'Addario, Kyle P. (2001). The impacts of emoticons on message interpretation in computer-mediated communication. Social Science Computer Review 19: 3, 324-347.

Wilson, Jason; Fuller, Glen \& McCrea, Christian (2013). Editorial: Troll theory? Fibreculture 22. Saatavilla: http://twentytwo.fibreculturejournal.org/ (luettu 9.9.2014). 